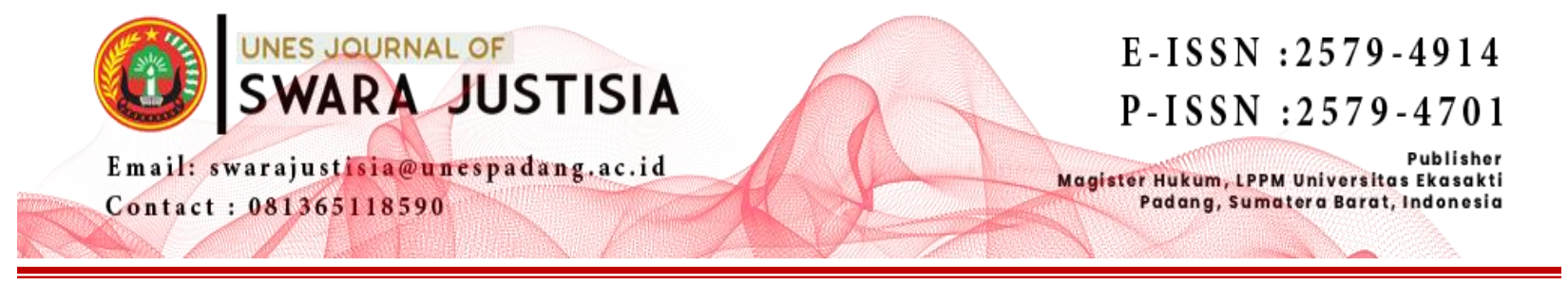

\title{
TINJAUAN HUKUM ISLAM TERHADAP UNDANG-UNDANG BIDANG KESEHATAN
}

\author{
${ }^{1)}$ Fitra Mulyawan, ${ }^{2)}$ Kiki yulinda \\ 1) Fakultas Hukum,Universitas Ekasakti, Padang, Indonesia \\ Email: moelyaftr@yahoo.com \\ 2) Fakultas Hukum,Universitas Ekasakti, Padang, Indonesia \\ Email: kiki.yulinda@gmail.com
}

\begin{abstract}
In the development of Indonesian National Law, the existence of Islamic law is very important, in addition to being a material for the preparation of national law, Islamic law is also an inspiration and dynamic in the development of national law. Likewise in the health sector, where the existence of Islamic law is an integral part of national law in the rules that exist in the health sector law. Intended to see whether Islamic law becomes an integral part of the rules in the field of health. Then whether the existence of Islamic law in these rules is explored from Islamic law which develops normatively into positive law. Therefore, Islamic law in the form of fatwas has a strong influence on the legislative process in Indonesia. All of this is clearly seen in the rules of health, first revealed elements of Islamic law that exist in the rules of health, namely the health law from independence to existing laws and apply to this day. So that the health law found a value system in Islam related to health, such as forbidden abortion, the existence of strict rules.
\end{abstract}

Keywords: Islamic Law, Health Sector

\begin{abstract}
ABSTRAK
Dalam perkembangan Hukum Nasional Indonesia, keberadaan hukum Islam sangat penting, selain sebagai materi bagi penyusunan hukum nasional, hukum Islam juga menjadi inspirator dan dinamisator dalam perkembangan hukum nasional. Begitu juga dalam bidang kesehatan, dimana keberadaan hukum Islam yang merupakan bagian integral dari hukum nasional dalam aturanaturan yang ada dalam undang-undang bidang kesehatan. Ditujukan untuk melihat apakah hukum Islam menjadi bagian integral dari aturan-aturan dalam bidang kesehatan. Kemudian apakah adanya hukum Islam dalam aturan-aturan tersebut memang digali dari hukum Islam yang berkembang secara normatif menjadi hukum positif. Oleh karena itu bahwa, hukum Islam dalam bentuk fatwa-fatwa mempunyai pengaruh kuat dalam proses legislasi di Indonesia. Semuanya itu terlihat jelas dalam aturan-aturan kesehatan, terlebih dahulu diungkapkan unsur-unsur hukum Islam yang ada dalam aturan-aturan tentang kesehatan yaitu undang-undang kesehatan sejak kemerdekaan sampai undang-undang yang ada dan berlaku sampai hari ini. Sehingga dalam undang-undang kesehatan tersebut ditemukan adanya sistem nilai dalam Islam yang berkaitan dengan kesehatan, seperti aborsi yang diharamkan, adanya aturan yang ketat terhadap
\end{abstract}


pelaksanaan transplantasi organ tubuh, zat adiktif/rokok, dan lain-lain sebagainya, dan semuanya itu di adopsi dari fatwa-fatwa MUI terhadap peraturan perundang-undangan.

Kata Kunci: Hukum Islam, Bidang Kesehatan.

\section{PENDAHULUAN}

Memiliki penduduk dengan mayoritas pemeluk agama Islam membuat Indonesia menempati satu dari sepuluh negara dengan jumlah muslim tertinggi di dunia dengan total 222 juta umat berdasarkan perhitungan dari Muslim Pro diikuti oleh Pakistan sebanyak 195 juta umat diurutan kedua dan India sebanyak 183 juta umat diurutan ketika per 2018. ${ }^{1}$ Sensus penduduk oleh Badan Pusat Statistik (BPS) pada 2010 mencatat bahwa jumlah umat muslim di Indonesia mencapai 207.176.162 jiwa atau sekitar $80 \%$ dari 237.641.326 jiwa penduduk Imdonesia memeluk agama Islam. ${ }^{2}$

Beberapa term digunakan Al-Qur'an untuk menunjukkan arti masyarakat ideal, yaitu terdiri atas ummatan wahida, ummatan wasathan, khoiru ummah dan baldatun thayyibah. Ummatan wahidah disebutkan dalam surat Al-Baqarah (2) ayat 213 yang mengatakan bahwa manusia dari dulu hingga sekarang merupakan satu umat, Allah SWT menciptakan mereka sebagai makhluk sosial yang saling berkaitan dan saling membutuhkan satu sama lain. Ummatan wasathan, khoiru ummah terdapat dalam surat Ali Imran (3) ayat 110 yang menyatakan untuk menjadi ideal, umat Islam seharusnya memiliki supremasi dalam segala bidang yaitu bidang ekonomi, politik, sosial, budaya, ilmu dan lain-lain karena ketakutan digalang dari semua aspek kehidupan. Baldatun thayyibah terdapat dalam Qur'an surat Saba (34) ayat 15 yang menyatakan bahwa jika suatu negeri dapat dikatakan memiliki tanah yang subur, penduduk yang makmur serta pemerintahan yang adil, maka dapat disebut sebagai masyarakat yang ideal (HA Kosasih, 2000:4). Kesehatan dapat dikategorikan ke dalam kondisi ideal umat muslim yaitu khoiru ummah. Sehat berasal dari bahasa Arab yaitu as-shihah yang berarti sembuh, sehat, selamat dari cela, cacat atau nyata, benar sesuai kenyataan (Sabas Wiradiuria, 2016:105). Dapat disimpulkan secara umum bahwa sehat berarti suatu keadaan dimana seluruh organ serta syaraf tubuh dapat berfungsi dengan baik tanpa adanya penyakit yang hinggap di tubuh. Dalam perkembangan Hukum Nasional Indonesia, keberadaan hukum Islam sangat penting, selain sebagai materi bagi penyusunan hukum nasional, hukum Islam juga menjadi inspirator dan dinamisator dalam perkembangan hukum nasional. Hukum Islam sangat dekat dengan sosioantropologis bangsa Indonesia, sehingga kehadirannya dapat dengan mudah diterima oleh masyarakat.

Seperti diketahui, berlainan dengan keberadaan hukum Islam dimasa-masa pemerintahan penjajahan Belanda yang diposisikan ke dalam hukum tidak tertulis bersama-sama dengan hukum adat, maka eksistensi hukum Islam bersama-sama hukum adat masih dianggap atau diposisikan sebagai hukum tidak tertulis (unwriten law). Keberadaan hukum Islam setelah proklamasi kemerdekaan Republik Indonesia terutama setelah dasawarsa 1970-an, beralih status

\footnotetext{
${ }^{1}$ http://support.muslimpro.com/hc/id/articles/115002006087-Top-10-Populasi-Umat-MuslimTerbesar-diDunia, diakses pada senin, 25 April 2020.

${ }^{2}$ https://bps.go.id, diakses pada senin, 25 April 2020.
} 
atau kelas dari hukum tidak tertulis menjadi hukum tertulis yaitu tertuang dalam bentuk peraturan perundang-undangan Negara Hukum Indonesia. Diawali dari sektor keluarga dengan diundangkannya Undang-Undang Republik Indonesia No. 1 Tahun 1974 tentang Perkawinan, kemudian diikuti dengan Peraturan Pemerintah No. 9 Tahun 1975 tentang Pelaksanaan Undangundang No. 1 Tahun 1974 tentang Perkawinan dan khusus bagi umat Islam, dikeluarkan Instruksi Presiden Republik Indonesia No. 1 Tahun 1991 tentang Kompilasi Hukum Islam.

Sejak tahun 1970 hingga sekarang, pengundangan atau taqninisasi hukum Islam di Negara Hukum Indonesia terus berjalan meskipun tidak jarang atau sering sekali mengalami hambatan dan atau tantangan. Proses taqninisasi hukum Islam atau Islamisasi perundangundangan di Indonesia, antara lain dapat dibaca dan dipelajari dari deretan hukum Islam yang sudah menjadi hukum nasional sebagai berikut: UU Perkawinan, UU Peradilan Agama, UU Penyelenggaraan Ibadah Haji, UU Pengelolaan Zakat, dan UU Otonomi Khusus Nanggroe Aceh Darussalam serta beberapa undang-undang lain, baik yang secara langsung maupun tidak langsung memuat hukum Islam seperti UU No. 10 Tahun 1998 tentang Perbankan yang mengakui keberadaan Bank Syari'ah dengan prinsip syari'ahnya, atau UU No. 3 Tahun 2006 tentang Peradilan Agama yang semakin memperluas kewenangannya, dan UU No. 21 Tahun 2008 tentang Perbankan Syari'ah. Untuk lebih mempertegas keberadaan hukum Islam dalam konstalasi hukum nasional dapat dilihat dari teori eksistensi tentang adanya hukum Islam di dalam hukum nasional Indonesia. Teori tersebut mengungkapkan bahwa bentuk eksistensi hukum Islam di dalam hukum nasional Indonesia, yaitu ada dalam arti sebagai bagian integral dari hukum nasional Indonesia, ada dalam arti kemandirian, kekuatan dan wibawanya diakui adanya oleh hukum nasional dan diberi status sebagai hukum nasional dan ada dalam arti sebagai bahan utama dan unsur utama hukum nasional Indonesia. Dengan demikian mendorong penulis untuk menyoroti tnjauan hukum Islam terhadap undang-undang bidang kesehatan.

\section{HASIL DAN PEMBAHASAN}

\section{Kedudukan Undang-Undang Bidang Kesehatan dalam Hukum Nasional Indonesia.}

\section{Undang-Undang No. 9 Tahun 1960 tentang Pokok-pokok Kesehatan}

Undang-undang No. 9 Tahun 1960 tentang Pokok-pokok Kesehatan yang dikeluarkan tanggal : 15 Oktober 1960 yang berisi VI BAB, 17 Pasal dan berisi tentang : Ketentuanketentuan Umum, Tugas-tugas Pemerintah, Alat Perlengkapan Pemerintah, Usaha Swasta, yang dalam aturan peralihannya menyebutkan bahwa undang-undang ini dibuat untuk membatalkan UU produk Belanda, het Reglement op de Dienst dervoksgezondheid. Dari pasal-pasal yang ada dalam undang-undang ini, menurut hemat penulis ada dua pasal yang berkaitan dengan hukum Islam, yaitu Pasal 8 dan Pasal 11.

Pasal 8 Ayat 1 berbunyi:

"Pemerintah berusaha agar keempatan untuk pengobatan dan perawatan bagi rakyat diberikan secara merata diseluruh wilayah Indonesia, dengan biaya bagi rakyat yang seringan-ringannya sampai kepada cuma-cuma".

Untuk usaha itu diadakan rumah sakit, poliklinik, lembaga-lembaga, rombonganrombongan kesehatan (umpamanya untuk jemaah haji), dan sebagainya. Pemerintah memberi 
kesempatan baik tenaga kesehatan maupun penderita dalam menjalankan ibadatnya. Dalam peraturan perburuhan, peraturan kepegawaian, peraturan pensiunan dan sebagainya, perlu soal-soal kesehatan, baik secara preventif maupun kuratif, diatur dengan seksama. Dalam pada itu diperhatikan juga, agar buruh dan pegawai tersebut di atas dilindungi terhadaphal-hal yang mengganggu atau membahayakan kesehatannya, dan diberi kesempatan untuk hiburan dan istirahat.

Dalam pasal ini ditemukan adanya aturan-aturan yang berkaitan dengan pemberian kesempatan untuk pelaksanaan ibadah tenaga kesehatan dan pasien. Yaitu pada kalimat rombongan-rombongan kesehatan (umpamanya untuk jemaah haji), dan sebagainya. "Pemerintah memberi kesempatan pada tenaga-tenaga kerohanian untuk membantu dan membimbing baik tenaga kesehatan maupun penderita dalam menjalankan ibadatnya".

Pasal 11:

1) Pemerintah berusaha mencukupi keperluan rakyat akan obat.

2) Pemerintah menguasai, mengatur dan mengawasi persediaan, pembuatan, penyimpanan, peredaran, dan pemakaian obat-obat (termasuk obat bius dan minuman keras), bahan obat, alat dan perbekalan lainnya.

3) Obat, bahan obat, alat dan perbekalan kesehatan yang dimaksud dalam ayat (2) harus memenuhi syarat-syarat yang ditetapkan dalam Farmakopee Indonesia dan peraturanperaturan lain.

4) Obat-obat asli Indonesia diselidiki dan dipergunakan sebaik-baiknya.

Dalam undang-undang kesehatan ini, sebagai hasil konversi dari aturan-aturan Belanda, ditemukan nuansa hukum Islam yang sangat sedikit. Sebagaimana dua pasal tersebut di atas. Aturan tersebut masih seputar aturan-aturan kesehatan secara umum. Karena undangundang ini adalah hasil terjemahan dari aturan kesehatan yang ada di Belanda. Unsur hukum Islam yang ditemukan di dalamnya hanyalah pengaturan minuman keras dan bimbingan beribadah bagi penderita.

\section{Undang-Undang No. 23 Tahun 1992 tentang Kesehatan}

Undang-undang No. 23 Tahun 1992 tentang Kesehatan perubahan atas UU No. 9

Tahun 1960 tentang Pokok-pokok Kesehatan, adalah yang menggabungkan aturan- aturan kesehatan yang telah ada, yaitu:

a. Undang-undang No. 3 Tahun 1953 tentang Pembukaan Apotik (Lembaran Negara Tahun 1953 No. 8).

b. Undang-undang No. 18 Tahun 1953 tentang Penunjukka Rumah Sakit-Rumah Sakit Partikulir yang Merawat Orang-orang Miskin dan Orang-orang yang Kurang Mampu (Lembaran Negara Tahun 1953 No. 48).

c. Undang-undang No. 9 Tahun 1960 tentang Pokok-pokok Kesehatan (Lembaran Negara Tahun 1960 No. 131, tambahan Le baran Negara No. 2068).

d. Undang-undang No. 11 Tahun 1962 tentang Hygiene Untuk Usaha-usaha Bagi Umum (Lembaran Negara Tahun 1962 No. 48, tambahan Lembaran Negara No. 2475).

e. Undang-undang No. 6 Tahun 1963 tentang Tenaga Kesehatan (Lembaran Negara Tahun 1963 No. 79, tambahan Lembaran Negara No. 2576).

f. Undang-undang No. 7 Tahun 1963 tentang Farmasi. 
g. Undang-undang No. 18 Tahun1964 tentang Wajib Kerja Tenaga Paramedis.

h. Undang-undang No. 2 Tahun 1966 tentang Hygiene.

i. Undang-undang No. 3 Tahun 1966 tentang Kesehatan Jiwa.

Dalam undang-undang tersebut di atas sudah mulai mengatur lebih luas tentang hukum Islam, karena sudah memuat aturan-aturan tentang Aborsi, Transpalasi organ tubuh/bedah plastik, Transfusi darah, Bayi tabung, dan Zat adiktif, namun belum mengatur tetang bayi tabung (kelahiran di luar rahim), dan donor darah. Disamping itu aturan-aturan lainnya yang berkaitan dengan pelaksanaan kesehatan.

\section{Undang-undang No. 36 Tahun 2009 tentang Kesehatan}

Setelah 17 tahun UU No. 23 Tahun 1992 tentang Kesehatan diberlakukan, maka UU tersebut dicabut dan diganti dengan UU tentang kesehatan yang baru, yaitu UU No. 36 Tahun 2009 tentang Kesehatan. Undang-undang ini terdiri dari 205 pasal dan 22 BAB.

Dari gambaran yang diungkapkan ini dapat dijelaskan bahwa undang-undang ini lebih rinci dan sudah lebih luas wewenangnya sesuai dengan perkembangan teknologi kesehatan dan informasi. Berikut ini hal-hal yang menjadi aturan-aturan kesehatan yang memiliki kaitan dengan hukum Islam.

a. Pasal 113, 114 dan 115 tentang Zat Adiktif

b. Passal 64, 65, 66, 67, 69 dan 70 tentang Transplantasi Organ Tubuh

c. Pasal 75, 76 dan 77 tentang Aborsi

d. Pasal 78 tentang Keluarga Berencana (vasektomi/tubektomi)

e. Pasal 86, 87, 88, 89, 90 dan 91 tentang Pelayanan Darah

f. Pasal 117 dan 123 tentang Bedah Mayat

g. Pasal 127 tentang Bayi Tabung

\section{Pandangan Hukum Islam Terhadap Undang-Undang Bidang Kesehatan}

Sebagaimana yang terdapat dalam aturan-aturan kesehatan yang berkaitan dengan hukum Islam, berikut ini penulis coba melihat unsur-unsur hukum Islam yag terdapat dalam aturan-aturan tersebut, namun hukum Islam yang dimaksud dalam penulisan ini lebih difokuskan pada hukum Islam yang bernuansa fatwa yang dikeluarkan oleh Majelis Ulama Indonesia (MUI), karena tidak dapat dipungkiri bahwa MUI dalam mengeluarkan fatwanya tidak sedikit mendasarkan keputusan fatwanya dengan melihat fatwa atau merujuk pendapat para fuqaha yang ada sebelumnya dalam masalah yang difatwakan. Ulasan-ulasan tersebut adalah sebagai berikut:

\section{Transpalansi Organ Tubuh Manusia}

Ada 3 tipe donor organ tubuh

a. Donor dalam keadaan hidup sehat: tipe ini memerlukan seleksi yang cermat dan pemeriksaan kesehatan yang lengkap, baik terhadap donor maupun resipien untuk menghindari kegagalan karena penolakkan tubuh oleh resipien dan untuk mencegah resiko bagi donor.

b. Donor dalam keadaan koma atau diduga akan meninggal dengan segera. Untuk tipe ini pengambilan organ donor memerlukan alat kontrol kehidupan misalnya alat bantu 
pernapasan khusus. Alat bantu akan dicabut setelah pengambilan organ selesai.

c. Donor dalam keadaan mati. Tipe ini merupakan yang ideal, sebab secara medis tinggal menunggu penentuan kapan donor dianggap meninggal secara medis dan yuridis (Dahlan, M.U, 1998:45-46).

Donor dalam keadaan sehat disini adalah donor anggota tubuh bagi siapa saja yang memerlukan pada saat si donor masih hidup. Donor semacam ini hukumnya boleh. Donor seperti ini diperbolehkan dengan syarat tidak mengakibatkan kematian si pendonor. Misalnya, dia mendonorkan jantung, limpha atau paru-parunya. Hal ini akan mengakibatkan kematian pada diri si pendonor. Padahal manusia tidak boleh membunuh dirinya, atau membiarkan orang lain membunuh dirinya, meskipun dengan kerelaannya. Sesuai firman Allah Swt dalam surat an-Nisa' (4) ayat 29:

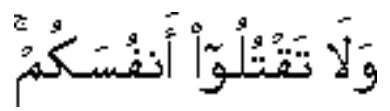

“.....Dan janganlah kamu membunuh dirimu (Qur'an, Asy-Syifaa, 2019:83) "

Selanjutnya dalam Surat al-An'am Allah juga berfirman:

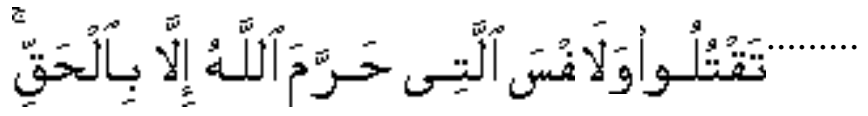

“.......Dan janganlah kamu membunuh jiwa yang diharamkan Allah (membunuhnya) melainkan dengan sesuatu (sebab) yang benar" (Qur'an, Asy- Syifaa, 2019:148).

Dengan demikian hukum Islam pun tidak membolehkan karena salah satu hadist mengatakan bahwa "Tidak boleh membahayakan diri sendiri dan tidak boleh membahayakan diri orang lain". (HR. Ibnu Majah).

Dalam hukum Islam, sebagian fuqaha membolehkan dan sebagian mengharamkan. Golongan yang membolehkan dengan syarat-syarat sebagai berikut:

a. Resipien (penerma organ) beada dalam keadaan darurat yang mengancam dirinya setelah menempuh berbagai upaya pengobatan yang lama.

b. Pencangkokan tidak akan menimbulkan akibat atau komplikasi yang lebih gawat.

c. Telah disetujui oleh wali atau keluarga korban dengan niat untuk menolong bukan untuk memperjual belikan.

Golongan yang tidak membolehkan dengan alasan: "Seseorang yang sudah mati tidak dibolehkan menyumbangkan organ tubuhnya atau mewasiatkan untuk menyumbangkannya. Karena seorang dokter tidak berhak memanfaatkan salah satu organ tubuh seseorang yang telah meninggal dunia untuk ditransplantasikan kepada orang yang membutuhkan. Adapun hukum kehormatan mayat dan penganiayaan terhadapnya, maka Allah SWT telah menetapkan bahwa mayat mempunyai kehormatan yang wajib dipelihara sebagaiman orang hidup. Dan Allah telah mengharamkan pelanggaran terhadap pelanggaran kehormatan mayat sebagaimana pelanggaran kehormatan orang hidup". Sebagaimana Rasulullah SAW bersabda yang diriwayatkan dari A'isyah Ummul Mu'minin RA:

"Memcahkan tulang mayat itu sama saja dengan memecahkan tulang orang hidup". 3

\footnotetext{
${ }^{3}$ H.R. Ahmad, Abu dawud, dan Ibnu Hibban (Hadist Viewer. Versi 9.1)
} 
Tindakan mengambil mata mayat atau membedah perutnya untuk diambil jantungnya atau ginjalnya atau hatinya untuk di trasplantasikan kepada orang lain yang membutuhkan dapat dianggap sebagai mencincang mayat. Padahal Islam telah melarang perbuatan ini. Imam Bukhari telah meriwayatkan dari Abdullah bin Zaid Al-Anshasi RA, dia berkata:

"Rasulullah telah melarang (mengambil) harta hasil rampasan dan mencincang (mayat musuh)". 4

Dalam Undang-undang No. 36 Tahun 2009 tetang Kesehatan, trasplantasi dinyatakan pada Pasal 64 sampai Pasal 70 sebagaiman yang telah dituliskan di atas.

Pertama, apabila pencangkokan tersebut dilakukan, di mana donor dalam keadaan sehat wal afiat, maka hukumnya menurut Prof. Drs. Masyfuk Zuhdi (Masyfuk Zuhdi, 1993:87), dilarang (haram) berdasarkan alasan-alasan sebagai berikut:

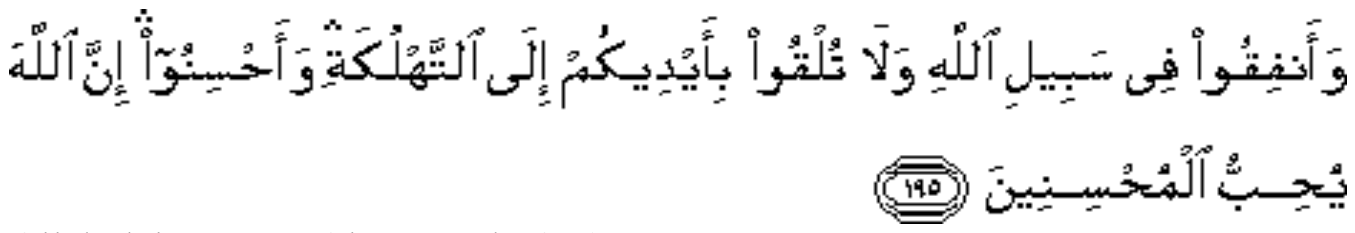

1) Firman Allah dalam surat Al-Baqarah: 195

"Dan belanjakanlah (harta bendamu) di jalan Allah, dan janganlah kamu menjatuhkan dirimu sendiri ke dalam kebinasaan, dan berbuat baiklah, karena sesungguhnya Allah menyukai orang-orang yang berbuat baik".

Dalam kasus ini, orang yang menyumbagkan sebuah mata atau ginjalnya kepada orang lain yang buta atau tidak mempunyai ginjal... ia (mungkin) akan menghadapi resiko sewaktuwaktu mengalami tidak normalnya atau tidak berfungsinya mata atau ginjalnya yang tinggal sebuah itu (Masyfuk Zuhdi, 1993:88).

2) Kaidah hukum Islam

"Menolak kerusakan harus didahulukan atas meraih kemaslahatan"

Dalam kasus ini, pendonor mengorbankan dirinya dengan cara melepas organ tubuhnya untuk diberikan kepada dan demi kemaslahatan orang lain, yakni resipien.

3) Kaidah hukum Islam

"Bahaya tidak boleh dihilangkan dengan bahaya lainnya".

Ini menjelaskan bahwa, bahaya yang mengancam seorang resipien tidak boleh diatasi dengan cara membuat bahaya dari orang lain, yakni pendonor.

Kedua, apabila transplantasi dilakukan terhadap donor yang dalam keadaan sakit (koma) atau hampir meninggal, maka hukum Islam pun tidak membolehkan (Masyfuk Zuhdi, 1993:89), berdasarkan alasan-alasan berikut:

a) Hadist Rasulullah:

Artinya: Tidak boleh membahayakan diri sendiri dan tidak boleh membahayakan diri

${ }^{4}$ H.R. Bukhari (Hadist Viewer. Versi 9.1). 


\section{orang lain ${ }^{5}$}

Dari sini dapat kita ketahui bahwa dharar (melakukan sesuatu yang membahayakan) dilarang di dalam syari'at ini. Maka tidak halal bagi seorang muslim mengerjakan sesuatu yang membahayakan dirinya atau membahayakan saudaranya sesama muslim. Dalam hal ini yaitu pendonor.

b) Orang tidak boleh menyebabkan matinya orang lain

Dalam hal ini maksudnya adalah orang yang sedang sakit (koma) akan meninggal dengan diambil organ tubuhnya tersebut. Sekalian tujuan dari pencakokan tersebut adalah mulia, yakni untuk menyembuhkan sakitnya orang lain (resipien).

Ketiga, apabila pencakokan dilakukan ketika pendonor telah meninggal, baik secara medis maupun yuridis, maka menurut hukum Islam ada yang membolehkan dan ada yang mengharamkan. Yang membolehkan menggantungkan pada dua syarat sebagai berikut:

a) Resipien dalam keadaan darurat, yang dapat mengancam jiwanya dan ia sudah menempuh pengobatan secara medis dan non medis, tapi tidak berhasil.

b) Pencangkokan tidak menimbulkan komplikasi penyakit yang lebih berat bagi resipien dibadingkan dengan keadaan sebelum pencangkokan.

Demikian ini sesuai dengan fatwa Majelis Ulama Indonesia yaitu:

a) Fatwa Majelis Ulama Indonesia No. 11 Tahun 2019 tentang Transplantasi dan/atau Jaringan Tubuh Untuk Diri Sendiri. Mengatakan bahwa: Transplantasi organ dan/atau jaringan tubuh orang yang hidup untuk diri sendiri diperbolehkan dengan ketentuan sebagai berikut: Pertama, terdapat kebutuhan yang dibenarkan secara syar'i, baik pada tingkatan al-hajah maupun ad-dlarurah. Kedua, tidak membahayakan diri sendiri. Ketiga, transplantai dilakukan oleh ahli yag kompeten dan kredibel. Transplantasi organ dan/atau jariangan tubuh sebagaimana poin 1 tidak dibolehkan jika hanya untuk kepentingan yang bersifat tahsiniyat.

b) Fatwa Majelis Ulama Indonesia No. 12 tahun 2019 tentang Transplantasi dan/atau Jaringan Tubuh Dari Pendonor Mati Untuk Orang Lain.

1) Seseorang tidak boleh memberikan atau menjual organ dan/atau jaringan tubuhnya kepada orang lain karena organ tubuh tersebut bukan hak milik (haqqul miliki). Untuk itu pengambilan dan transplantasi organ dan/atau jaringan tubuh tanpa alasan yang dibenarkan secara syar'i hukumnya haram.

2) Transplantasi organ dan/atau jaringan tubuh orang yang meninggal kepada orang yang hidup dibolehkan dengan ketentuan sebagai berikut:

3) Kebolehan transplantasi organ dan/atau jaringan tubuh sebagaimana dimaksud angka 2 (dua) tidak termasuk bagi organ reproduksi, organ genital, dan otak.

c) Fatwa Majelis Ulama Indonesia No. 13 Tahun 2019 tentang Transplantasi Organ dan/atau Jaringan Tubuh dari Pendonor Hidup Untuk Orang Lain.

${ }^{5}$ H.R. Imam Ahmad 1/313. Ibnu Majah dalam Kitab Al-Ahkam, Bab Man bana bihaqqihi ma yadhurru jarahu, No. 2341, At-Thabrani dalam Al-Kabir, No. 11806 dari Jabir al-Ja'fi dari Ikrimah dari Ibnu Abbas Radhiyallahu anhu. 
1) Seseorang tidak boleh memberikan atau menjual organ dan/atau jaringan tubuhnya kepada orang lain karena organ tubuh tersebut bukan hak milik (haqqul milki). Untuk itu, pengambilan dan transplantasi organ tubuh tanpa adanya alasan yang dibenarkan secara syar'i hukumnya haram.

2) transplantasi organ dan/atau jaringan tubuh pendonor hidup kepada orang lain dibolehkan dengan ketentuan sebagai berikut:

3) Kebolehan transplantasi organ dan/atau jaringan tubuh sebagaimana dimaksud pada angka 2 (dua) tidak termasuk bagi organ reproduksi, organ genital, dan otak.

Apabila transplantasi organ tubuh diambil dari orang yang masih dalam keadaan

hidup sehat, maka hukumnya haram, dengan alasan menimbang akibatnya yang kemungkinan bisa berakibat fatal bagai diri donor, walaupun perbuatan itu mempunyai tujuan kemanusiaan yang baik dan luhur. Umpamanya seseorang menyumbangkan sebuah ginjalnya atau matanya pada orang lain yang memerlukannya karena hubungan keluarga, teman atau karena berharap adanya imbalan dari orang yang memerlukan dengan alasan krisis ekonomi (MB Hooker, 1999:167).

\section{Aborsi}

Aborsi menurut etimologi berasal dari bahasa Inggris abortion: miscarriage, yang berarti pengguguran kandungan. Abortus artinya keguguran. Aborsi menurut terminologi adalah abortion (n): expultion of foetus from tlie womb during the first 28 weeks ofpregnance (AS. Harley, AP Cowie, 1987:2).

Aborsi atau abortus menurut hukum pidana, yaitu kejahatan yang dilakukan dengan suatu perbuatan yang mengakibatkan kandungan lahir sebelum waktunya melahirkan menurut alam. Pada tindak kejahatan terhadap peng-guguran kandungan ini diartikan juga sebagai pembunuhan anak yang berencana, di mana pada pengguguran kandungan harus ada kandungan (vrucht) atau bayi (kidn) yang hidup yang kemudian dimatikan. Persamaan inilah yang juga menyebabkan tindak pidana penguguran (abortus) dimasukkan ke dalam titel buku II KUHP tentang kejahatan terhadap nyawa orang.

Menurut mayoritas fukaha, melakukan aborsi bagi janin yang telah berusia 120 hari hukumnya haram. Sedang usia sebelum 120 hari terjadi khilâfiyah. Ada yang berpendapat boleh, makrûh, dan haram. Alasan yang mengharamkan usia 120 hari dan membolehkan sebelum 120 hari adalah hadis yang diriwayatkan oleh Muslim dan Ibn Mas'ud yang menyatakan tentang penciptaan janin, dari nuthfah ke 'alaqah, ke mudghah dan sampai ditiupkannya ruh pada usia ke 40 hari (Hassan Hathaoud, 1995:167). Fatwa Majelis Ulama Indonesia Nomor: 4 Tahun 2005 Tentang Aborsi Janin

Terindikasi Penyakit Genetik, menyebutkan sebagai berikut:

a. Aborsi haram hukumnya sejak terjadinya implantasi blastosis pada dinding rahim ibu (nidasi).

b. Aborsi dibolehkan karena ada uzur, baik bersifat darurat ataupun hajat.

1) Keadaan darurat yang berkaitan dengan kehamilan yang membolehkan aborsi antara lain perempuan hamil menderita sakit fisik berat seperti kanker stadium lanjut, TBC 
dengan caverna dan penyakit-penyakit fisik berat lainnya yang harus ditetapkan oleh tim dokter dan dalam keadaan di mana kehamilan mengancam nyawa si ibu.

2) Keadaan hajat yang berkaitan dengan kehamilan yang dapat membolehkan aborsi antara lain janin yang dikandung dideteksi menderita cacat genetik yang kalau lahir kelak sulit disembuhkan, kehamilan akibat perkosaan yang ditetapkan oleh tim yang berwenang yang di dalamnya terdapat antara lain keluarga korban, dokter, dan ulama dan kebolehan aborsi sebagaimana dimaksud huruf (b) harus dilakukan sebelum janin berusia 40 hari.

c. Aborsi haram hukumnya dilakukan pada kehamilan yang terjadi akibat zina (Himpunan Fatwa Majelis Ulama Indonesia, 2011:463).

Dari fatwa tersebut dapat dijelaskan bahwa aborsi bisa dilakukan bila kehamilan disebabkan oleh kasus pemerkosaan dan inses (hubungan sedarah). Dan syaratnya aborsi hanya diizinkan bila usia janin dalam kandungan belum mencapai 40 hari. Selain itu, dikeluarkan fatwa boleh menggugurkan janin, bila secara genetis janin yang dikandung kelak akan menjadi masalah dikemudian hari, dengan usia janin tak lebih dari 40 hari.

\section{Bedah Mayat (otopsi)}

Dalam fatwa MUI No. 6 Tahun 2009 tentang Otopsi Jenazah, yaitu:

a. Pada dasarnya setiap jenazah harus dipenuhi hak-haknya, dihormati keberadaannya dan tidak boleh dirusak.

b. Otopsi jenazah dibolehkan jika ada kebutuhan yang ditetapkan oleh pihak yang punya wewenang untuk itu.

c. Otopsi jenazah sebagaimana dimaksud angka 2 harus memenuhi ketentuan sebagai berikut: Otopsi jenazah didasarkan kepada kebutuhan yang dibenarkan secara syar'i (seperti mengetahui penyebab kematian untuk penyelidikan hukum, penelitian kedokteran, atau pendidikan kedokteran), ditetapkan oleh orang atau lembaga yang berwenang dan dilakukan oleh ahlinya, Otopsi merupakan jalan keluar satu-satunya dalam memenuhi tujuan sebagaimana dimaksud pada point a, Jenazah yang diotopsi harus segera dipenuhi hak-haknya, seperti dimandikan, dikafani, dishalatkan, dan dikuburkan dan Jenazah yang akan dijadikan obyek otopsi harus memperoleh izin dari dirinya sewaktu hidup melalui wasiat, izin dari ahli waris, dan/atau izin dari Pemerintah sesuai dengan ketentuan peraturan perundang-undangan (Himpunan Fatwa Majelis Ulama Indonesia, 2011:544$545)$.

\section{KB (Tubektomi dan Vasektomi)}

Masalah vasektomi telah difatwakan oleh MUI sebanyak empat kali, yaitu fatwa tahun 1979, fatwa tahun 1983, fatwa tahun 2009, dan terakhir fatwa tahun 2012. Setiap fatwa tentang vasektomi dari 4 (empat) kali penetapan fatwa akan dikemukakan Diktum Fatwa atau Naș Fatwa, sehingga nantinya dapat dilihat dengan jelas maupun samar- samar bagaimana metode istinbāt-nya, atau alasan rasional mengapa hukum tersebut ditetapkan. Di antara alasan rasional itu, ada yang wujudnya 'illat hukum. Diktum fatwa-fatwa tersebut sebagai berikut: 
a. Fatwa MUI Tahun 1979 tentang Vesektomi

Vasektomi hukumnya haram, karena: 1) Pemandulan dilarang oleh agama. 2) Vasektomi/tubektomi adalah salah satu usaha pemandulan 3) Di Indonesia belum dapat dibuktikan bahwa vasektomi/ tubektomi dapat disambung kembal.

b. Fatwa MUI Tahun 1983 tentang Vasektomi

1) Melakukan vasektomi (usaha mengikat atau memotong saluran benih pria (vas deferens), sehingga pria itu tidak dapat menghamilkan) dan tubektomi (usaha mengikat atau memotong kedua saluran telur, se-hingga wanita itu pada umumnya tidak dapat hamil lagi) bertentangan dengan Hukum Islam (haram), kecuali dalam keadaan sangat terpaksa (darurat) seperti untuk menghindarkan penularan penyakit dari ibu/bapak terhadap anak keturunannya yang bakal lahir atau ter- ancamnya jiwa si janin apabila ia mengandung atau melahirkan lagi.

2) Menganjurkan kepada pemerintah untuk melarang pelaksanaan vasektomi, tubectomi dan abortus bagi Umat Islam, serta meningkatkan pengawasan terhadap penyalahgunaan alat-alat kontrasepsi yang ada kemungkinan dipergunakan untuk perbuatan maksiat.

c. Fatwa MUI Tahun 2009 tentang Vasektomi

1) Vasektomi sebagai alat kontrasepsi $\mathrm{KB}$ sekarang ini dilakukan dengan memotong saluran sperma. Hal itu berakibat terjadinya kemandulan tetap.

2) Upaya rekanalisasi (penyambungan kembali) tidak menjamin pulihnya tingkat kesuburan kembali yang bersangkutan.

d. Fatwa MUI Tahun 2012 tentang Vasektomi Vasektomi hukumnya haram, kecuali:

1) Untuk tujuan yang tidak menyalahi syari'at.

2) Tidak menimbulkan kemandulan permanen.

3) Ada jaminan dapat dilakukan rekanalisasi yang dapat mengembalikan fungsi reproduksi seperti semula.

4) Tidak menimbulkan bahaya (maḍarat) bagi yang bersangkutan.

5) Tidak dimasukkan ke dalam program dan metode kontrasepsi mantap (Himpunan Fatwa Majelis Ulama Indonesia, 2011:544-545).

\section{Zat Adiktif/Rokok/Heroin}

Setelah melalui draf awal, dilanjutkan dalam sidang pleno komisi, ditampung dalam tim perumus kemudian diajukan ke sidang pleno Ijtima' Ulama Komisi Fatwa MUI yang berlansung pada hari Ahad 26 Januari 2009, dicapai keputusan yang diktumnya sebagai berikut:

a. Seluruh peserta sidang pleno ijtima' sepakat: Bahwa hukum merokok tidak wajib, Bahwa hukum merokok tidak sunat dan Bahwa hukum merokok tidak mubah.

b. Peserta sidang berbeda pendapat tentang tingkat larangan merokok tersebut, sehingga hukum merokok terjadi khilaf ma baiyna al-mak ruh wa al-haram (perbedaan anatara haram dan makruh).

c. Seluruh peserta sidang pleno ijtima' sepakat bahwa merokok hukumnya haram: Di tempat 
umum, bagi anak-anak dan bagi wanita hamil.

Sementara dalam UU Kesehatan yang membicarakan tentang zat adiktif juga menjelaskan tentang tempat merokok yang boleh sesuai dengan yang ada dalam fatwa MUI tersebut di atas pada Pasal 115 (1) Kawasan tanpa rokok antara lain: fasilitas layanan kesehatan, tempat proses belajar mengajar, tempat anak bermain, tempat ibadah, angkutan umum, tempat kerja dan tempat umum dan tempat lain yang ditetapkan.

\section{KESIMPULAN}

Berdasarkan atas pembahasan sebagaimana telah diuraikan di atas maka dapat ditarik kesimpulan sebagai berikut:

1. Ditemukan adanya sistem nilai dalam Islam yang berkaitan dengan kesehatan, seperti aborsi yang diharamkan, adanya aturan yang ketat terhadap pelaksanaan transplantasi organ tubuh, zat adiktif/rokok, dan hal-hal lain di bidang kesehatan yang diatur di dalam UU No. 36 Tahun 2009 tentang Kesehatan.

2. Fatwa Majelis Ulama Indonesia merupakan usaha dari para ulama untuk mengatur kegiatan agama yang menjadi kebutuhan dan kepentingan umat. Dalam hal ini tergambar bahwa unsurunsur hukum Islam yang di adopsi dari fatwa-fatwa MUI terhadap peraturan perundangundangan. MUI telah memberi respon terhadap sejumlah masalah kesehatan sebagai upayanya untuk menjawab tantangan kemajuan zaman dan memberikan bimbingan kepada umat Islam. Sebagian fatwa MUI ternyata telah direspon oleh masyarakat dan pemerintah serta diadopsi dengan berbagai modifikasi dalam legislasi di Indonesia.

\section{DAFTAR PUSTAKA}

\section{Buku-Buku}

AS. Harley, AP Cowie, Ac Ginson Oxford Advenced Teories Dictionary of Corent English, Toronto Oxford University, New York, 1987.

Dahlan, M.U, Pengantar Hukum Kesehatan, Korpri Sub Unit Kanwil Depkes, Surabaya, 1998.

HA Kosasih, Konsep Masyarakat Madani, Universitas Pendidikan Indonesia, Bandung, 2000.

Hassan Hathaoud, Revolusi Seksual Perempuan, Mizan, Bandung, 1995.

H.R. Imam Ahmad 1/313. Ibnu Majah dalam Kitab Al-Ahkam, Bab Man bana bihaqqihi ma yadhurru jarahu, No. 2341, At-Thabrani dalam Al-Kabir, No. 11806 dari Jabir al-Ja'fi dari Ikrimah dari Ibnu Abbas Radhiyallahu anhu.

Masyfuk Zuhdi, Masail Fiqh 1, PT. Bima Aksara, Jakarta, 1993.

MB Hooker, Islam dari Ilmu Kesehatan: Bukti-bukti Fatwa Indonesia Tahun 1960-1995. Dalam Buku Indonesia: Law and Society, NSW: The Federation Press, Timoty Linsey, 1999, hlm. 
Qur'an, Asy-Syifaa, Hafalan Terjemahan \& Tajwid Berwarna Metode Tikrar, Cetakan Kelima, Sygma Creative Media Corp, Bandung, 2019.

Sabas Wiradiuria, Menggapai Kesembuhan Sebuah Harapan dan Peluang Menapaki Jalan Kebahagiaan, Paramedia Komunikatama, Bandung, 2016.

\section{Undng-Undang}

Undang-Undang Republik Indonesia No. 9 Tahun 1960 tentang Pokok-pokok Kesehatan

Undang-Undang Republik Indonesia No. 23 Tahun 1992 tentang Kesehatan

Undang-Undang Republik Indonesia Nomor 36 Tahun 2009 tentang Kesehatan Himpunan Fatwa Majelis Ulama Indonesia Sejak 1975, Erlangga, Jakarta, 2011.

\section{Internet}

https://bps.go.id, diakses pada senin, 29 April 2020.

http://support.muslimpro.com/hc/id/articles/115002006087-Top-10-Populasi-Umat-MuslimTerbesar-di-Dunia, diakses pada senin, 29 April 2020. 